\title{
Biliary Physiology in Rats with Bile Ductular Cell Hyperplasia Evidence for a Secretory Function of Proliferated Bile Ductules
}

\author{
Gianfranco Alpini, Renato Lenzi, Laszlo Sarkozi, and Nicola Tavoloni \\ Department of Medicine, Polly Annenberg Levee Hematology Center, and Department of Chemistry,
} Mount Sinai School of Medicine of the City University of New York, New York 10029

\begin{abstract}
To establish the role of the biliary epithelium in bile formation, we studied several aspects of biliary physiology in control rats and in rats with ductular cell hyperplasia induced by a 14-d extrahepatic biliary obstruction. Under steady-state conditions, spontaneous bile flow was far greater in obstructed rats $(266.6 \pm 51.9 \mu \mathrm{l} / \mathrm{min}$ per $\mathrm{kg})$ than in controls $(85.6 \pm 10.6 \mu \mathrm{l} /$ min per $\mathrm{kg}$ ), while excretion of 3-hydroxy bile acids was the same in the two groups. Infusion of 10 clinical units (CU)/ $\mathbf{k g}$ per $\mathbf{h}$ secretin produced a minimal choleretic effect in controls $(+3.8 \pm 1.9 \mu \mathrm{l} / \mathrm{min}$ per $\mathrm{kg})$ but a massive increase in bile flow in the obstructed animals $(+127.8 \pm 34.9 \mu \mathrm{l} / \mathrm{min}$ per $\mathrm{kg})$. Secretin choleresis was associated with an increase in bicarbonate biliary concentration and with a decline in $\left[{ }^{14} \mathrm{C}\right]$ mannitol bile-toplasma ratio, although solute biliary clearance significantly increased. Conversely, administration of taurocholate $(5$ $\mu \mathrm{mol} / \mathrm{min}$ per $\mathrm{kg}$ ) produced the same biliary effects in control rats and in rats with proliferated biliary ductules. In the obstructed animals, the biliary tree volume measured during taurocholate choleresis $(67.4 \pm 15.8 \mu \mathrm{l} / \mathrm{g}$ liver) was significantly greater than that determined during the increase in bile flow induced by secretin $(39.5 \pm 10.4 \mu \mathrm{l} / \mathrm{g}$ liver). These studies indicate that, in the rat, the proliferated bile ductules/ducts spontaneously secrete bile and are the site of secretin choleresis. Furthermore, because the proliferated cells expressed phenotypic traits of bile ductular cells, our results suggest that whereas under normal conditions the biliary ductules/ducts in the rat seem to contribute little to bile formation, secretion of water and electrolytes is a property of biliary epithelial cells.
\end{abstract}

\section{Introduction}

Current concepts indicate that bile is formed primarily at the bile canaliculus where osmotic gradients, generated by the biliary translocation of bile acids and/or other unidentified molecules, allow net movement of water from plasma into the canalicular lumen $(1,2)$. Before reaching the duodenum or the gallbladder, however, canalicular bile is thought to be signifi-

Portions of this study were presented at the American Association for the Study of Liver Diseases Meeting, Chicago, IL, 4 and 5 November 1986, and were published in abstract form (1986. Hepatology [Baltimore]. 6:1192).

Address correspondence and reprint requests to N. Tavoloni, Ph.D., Division of Hematology, Atran Building, Box 1079, Mount Sinai Medical Center, 100th Street and Madison Ave., New York, NY 10029.

Received for publication 9 March 1987 and in revised form 10 September 1987.

J. Clin. Invest.

(C) The American Society for Clinical Investigation, Inc.

$0021-9738 / 88 / 02 / 0569 / 10 \quad \$ 2.00$

Volume 81, February 1988, 569-578 cantly modified while flowing through the collecting bile ductules and ducts. Support for a role of biliary epithelium in bile formation has been obtained primarily in the dog in which studies of electrolyte biliary secretion (3), secretin choleresis (4), inert carbohydrate biliary clearance $(5,6)$, "white bile" formation (7), and water and electrolyte movement across an isolated segment of the extrahepatic bile duct (8) are all consistent with the hypothesis that both secretory and reabsorptive mechanisms are operative at sites distal to the hepatic parenchyma. At least in the rat, however, no convincing evidence supports a transport function of biliary epithelial cells. Goldfarb et al. (9) suggested that the biliary epithelial structures in the rat secrete water and electrolytes based on the observation that ductular cell hyperplasia (DCH) ${ }^{1}$ associated with chronic $\alpha$-naphthylisothiocyanate feeding resulted in hydrocholeresis. Similarly, Kountouras et al. (10) recently demonstrated an increased responsiveness to the choleretic effect of secretin in rats with DCH induced by prolonged biliary obstruction (BO). In neither report, however, was evidence presented to support the concept that the distal biliary ductules/ducts were indeed responsible for the increased secretory activity.

In the present studies, we have attempted to obtain more direct evidence for a role of biliary epithelium in bile formation in the rat by resorting to a strategy similar to that described by Goldfarb et al. (9) and Kountouras et al. (10). We have induced DCH by chronic BO and studied the effect of taurocholate, which is known to stimulate canalicular bile flow, and secretin, the choleretic effect of which is thought to originate at the bile ductules/ducts (4), on bile flow and composition in both control rats and rats with DCH. Subsequently, because DCH was associated with a massive increase in bile secretion both under spontaneous conditions and during secretin administration, we carried out a number of experiments to establish the origin of the increased secretory activity and the nature of the proliferating cells. Our results provide conclusive evidence that the proliferated bile-ductlike structures secrete water and electrolytes both spontaneously and under the effect of secretin. Moreover, because the proliferated cells expressed phenotypic traits of bile ductular cells, the present findings indicate that such a secretory activity is an important property of proliferated biliary epithelial cells, which may be of physiologic relevance.

\section{Methods}

Animals and induction of ductular cell hyperplasia. Male SpragueDawley rats, weighing 220-280 g, were obtained from Perfection Breeders, Douglasville, PA, and housed in a temperature-controlled

1. Abbreviations used in this paper: $\mathrm{BO}$, extrahepatic biliary obstruction; B/P, bile-to-plasma ratio; BTV, biliary tree volume; $\mathrm{DCH}$, bile ductular cell hyperplasia; G-6-P, glucose-6-phosphatase; $\gamma$-GT, $\gamma$-glutamyl transpeptidase. 
room $\left(22^{\circ} \mathrm{C}\right)$ with alternate 12 -h light-dark cycles for at least a week before being used. The animals were fed standard lab chow ad libitum, had free access to water, and were not fasted before use. DCH was induced by $\mathrm{BO}$ which was in turn produced as described by Accatino et al. (11). Under pentobarbital anesthesia $(50 \mathrm{mg} / \mathrm{kg}$, i.p.), the common bile duct was cannulated (PE 50 cannula, Clay-Adams, New York, NY) through a small abdominal incision. After free flow of bile was established, the bile duct cannula (4-5 cm long) was sealed at its open end with a flame and secured to the abdominal wall with several ligatures. The abdomen was then sutured, and the animal allowed to recover and kept in a standard rat cage under the conditions described above. During the obstruction period, some $\mathrm{BO}$ animals died, but the mortality rate never exceeded $40 \%$ and was much less during the first $12 \mathrm{~d}$ of BO (10-20\%). All surgically obstructed animals lost significant weight by the end of the first week of BO (15-20\% of their original weight), but partially recovered during the remaining 5-8 d. In all instances, only those rats which at the time of experiment had not lost $>15 \%$ of their original body weight ( $\sim 80 \%$ of survivors) were used in these studies. Control rats (sham-operated) underwent laparotomy but no $\mathrm{BO}$ was induced.

Studies of biliary physiology. These experiments were carried out 14 $\mathrm{d}$ after induction of BO, or 12-14 d after animals were sham-operated (controls). In both groups of rats, we measured bile flow and composition, the biliary clearance of $\left[{ }^{14} \mathrm{C}\right]$ mannitol and $\left[{ }^{3} \mathrm{H}\right]$ sucrose (Amersham Corp., Arlington Heights, IL), and the choleretic effects of taurocholate (Sigma Chemical Co., St. Louis, MO) and secretin (Kabi AB, Greenwich, CT). Secretin-Kabi preparation contains a lyophilized, highly purified natural porcine hormone with a potency of at least 3,000 clinical units $(\mathrm{CU}) / \mathrm{mg}$ peptide and no contaminating bile acids. All animals were anesthetized with pentobarbital sodium $(50 \mathrm{mg} / \mathrm{kg}$, i.p.) and surgically prepared for bile collection by cannulating the trachea (PE 205), both internal jugular veins (PE 50, for fluid infusion), one carotid artery (PE 60, for blood withdrawal) and, in those rats receiving $\left[{ }^{14} \mathrm{C}\right]$ mannitol and $\left[{ }^{3} \mathrm{H}\right]$ sucrose, by ligating the renal pedicles. In $\mathrm{BO}$ rats, the bile duct cannula previously installed was freed from the abdominal ligatures, exteriorized, cut at its occluded end, and connected to a PE 90 cannula (6-8 cm long) to allow collection of bile. In control rats, the common bile duct was cannulated with a PE 50 cannula following a midline abdominal incision. Of the 15 BO rats scheduled for studies of bile formation, only 10 could be used. In two rats, there was no bile flow after the mechanical obstruction was released. At autopsy, the distended extrahepatic bile ducts were found to be filled with a highly pigmented, tarry material. In three rats, bile was flowing normally but traces of blood were present. As expected, no difficulties were encountered with control rats.

In all animals, bile was collected for an initial 10-20-min period to obtain a blood and bile sample for background purposes. Thereafter, an infusion of $\left[{ }^{14} \mathrm{C}\right]$ mannitol $(\sim 0.3 \mu \mathrm{Ci} / \mathrm{h}$, i.v. $)$ and $\left[{ }^{3} \mathrm{H}\right]$ sucrose $(\sim 0.5 \mu \mathrm{Ci} / \mathrm{h}$, i.v. $)$ was started and, when bile flow rate reached steady state (70-90 min from the beginning of bile collection), taurocholate was infused at $5 \mu \mathrm{mol} / \mathrm{min}$ per $\mathrm{kg}$ for 30-50 min, followed by an equilibration period (usually $60 \mathrm{~min}$ ), and by an infusion of secretin at $10 \mathrm{CU} / \mathrm{kg}$ per h for $30-40 \mathrm{~min}$. After a final collection period of 60 min, the animal was killed with an overdose of pentobarbital, the liver removed, and its weight determined. Liver samples $(0.5-1.4 \mathrm{~g})$ were obtained for hepatic water content determination. Throughout the experiment, the animal was kept at $37^{\circ} \mathrm{C}$ and bile and blood were collected every $10 \mathrm{~min}$. Blood was obtained at the midpoint of each bile collection period as previously described (12). All solutions for intravenous infusion were prepared in Krebs-Henseleit bicarbonate solution, and fluid infusion rates were established using as a reference index the rate of bile flow and the value of the arterial hematocrit determined every $10 \mathrm{~min}$. The hematocrit remained constant $(42-46 \%$ in controls and $35-39 \%$ in BO rats) when the total rate of fluid infusion exceeded that of bile flow by at least $2 \mathrm{ml} / \mathrm{h}$. Similarly, plasma concentrations of $\left[{ }^{14} \mathrm{C}\right]$ erythritol and $\left[{ }^{3} \mathrm{H}\right]$ sucrose were roughly constant during the experiment, although a slight but progressive increase in $\left[{ }^{3} \mathrm{H}\right]$ sucrose concentrations occurred with time in some studies.
Measurement of biliary tree volume. To determine the site at which secretin produces choleresis, we measured the biliary tree volume (BTV) during taurocholate choleresis and compared it with that obtained during secretin administration. Experiments were carried out in four control rats and in six rats obstructed for $14 \mathrm{~d}$. Animals were surgically prepared as described above and infused with $\left[{ }^{14} \mathrm{C}\right]$ taurocholate (New England Nuclear, Boston, MA; sp act, $46.7 \mathrm{mCi} / \mathrm{mmol}$ ) at $0.5 \mu \mathrm{Ci} / \mathrm{h}$ to estimate the biliary transit time. BTV was determined during infusion of $5 \mu \mathrm{mol} / \mathrm{min}$ per $\mathrm{kg}$ taurocholate and $10 \mathrm{CU} / \mathrm{kg}$ per h secretin as described by Wheeler and Mancusi-Ungaro (4). Throughout the experiment, bile was collected every $3 \mathrm{~min}$, except during the first 60-min equilibration period in which bile collections were made over 10-min intervals (see Fig. 5 for a representative experiment).

Hepatic histology and histochemistry. Liver samples for light microscopy were obtained from a control rat and from rats sacrificed at 7 $(n=1), 12(n=1), 14(n=2), 16(n=1)$, and $28(n=1) \mathrm{d}$ after BO was induced. Liver blocks were obtained from anesthetized animals (pentobarbital sodium, $50 \mathrm{mg} / \mathrm{kg}$ i.p.), fixed in buffered formalin, and processed for hematoxylin and eosin (H \& E) staining by standard procedures. DCH was also assessed by histochemical analysis of $\gamma$-glutamyl transpeptidase $(\gamma-\mathrm{GT})$ which, in normal rat liver, is a reliable histochemical marker of biliary epithelial cells (13). Staining for $\gamma-G T$ was carried out in four control livers and in the same six BO livers used for hepatic histology. The assay was performed on frozen sections permeabilized in cold acetone for $10 \mathrm{~min}$ as described by Rutenberg et al. (14).

Isolation and purification of hepatocytes and nonparenchymal liver cells. To quantitate DCH and to assess the phenotypic traits of parenchymal and nonparenchymal liver cells in rats with $\mathrm{DCH}$, we isolated hepatocytes and nonparenchymal liver cells from control rats and from rats with DCH (13-14 d after obstruction was produced). Hepatocytes were isolated by a standard collagenase perfusion followed by differential centrifugation. The undissociated tissue was used for isolation of nonparenchymal liver cells as described previously (15). Suspensions of hepatocytes and nonparenchymal liver cells were then purified by centrifugal elutriation (J2-21 centrifuge equipped with a JE-6B rotor; Beckman Instruments, Inc., Fullerton, CA). The elutriating fluid was MEM medium (Gibco, Grand Island, NY) containing $10 \%$ calf serum and $0.006 \%$ DNase (Sigma Chemical Co.). Debris, red blood cells, and dead cells were removed at pump flow rates of 9-13 $\mathrm{ml} / \mathrm{min}$ (rotor speed, $1,000 \mathrm{rpm}$ for hepatocytes and 2,500 rpm for nonparenchymal liver cells). Hepatocytes and nonparenchymal liver cells were obtained as blow-out fractions (rotor rpm, 0) at a pump flow rate of $20 \mathrm{ml} / \mathrm{min}$. Aliquots of hepatocyte and nonparenchymal liver cell suspensions were used for determining cell concentration, size distribution, and cell viability (trypan blue exclusion). Several cell smears were also prepared, air dried, and some fixed in glutaraldehyde $(1 \%)$, while others were immersed in cold acetone $\left(-20^{\circ} \mathrm{C}\right)$ for $10 \mathrm{~min}$. Smears were used immediately or stored at $-70^{\circ} \mathrm{C}$.

Cytochemistry and immunocytochemistry techniques. Smears of hepatocytes and nonparenchymal liver cells fixed in glutaraldehyde were used for cytochemical expression of glucose-6-phosphatase (G-6P) as described by Wachstein and Meisel (16). Acetone-treated cell smears were instead used for cytochemical expression of $\gamma-\mathrm{GT}$, immunofluorescent detection of albumin and $\alpha$-fetoprotein, and immunoperoxidase demonstration of cytokeratin. $\gamma$-GT activity was determined as described by Rutenberg et al. (14). For immunofluorescent detection of albumin, cell smears were incubated at $22^{\circ} \mathrm{C}$ for $60 \mathrm{~min}$ with fluoresceine-conjugated, goat anti-rat albumin antibodies (Cooper Biochemical Inc., Malvern, PA). For $\alpha$-fetoprotein expression, cell smears were incubated with fluorescein-conjugated sheep anti-rat $\alpha$ fetoprotein antibodies (Nordic Immunological Laboratories, Capistrano Beach, CA) for $60 \mathrm{~min}$ at $22^{\circ} \mathrm{C}(\mathrm{pH} \mathrm{7.2)}$. Cytokeratin was detected by incubating cell smears $\left(60 \mathrm{~min}\right.$ at $\left.22^{\circ} \mathrm{C}, \mathrm{pH}=7.4\right)$ with a cocktail of mouse monoclonal antibodies reactive against keratins No. 8, 14, 15, 16, 18, and 19 (Triton Biosciences, Alameda, CA). After washing, smears were incubated with affinity-purified, peroxidaseconjugated sheep anti-mouse IgG (Sigma Chemical Co.). As a positive 
control for $\alpha$-fetoprotein, we used smears of acetone-treated hepatocytes isolated from fetal rat livers at day 16 of gestation. In all immunoassays, control smears were always incubated with the respective nonimmune serum or IgG (Sigma Chemical Co.). Hepatocytes (fetal and adult) and nonparenchymal liver cells never showed positive staining when nonimmune sera were used.

Analytical procedures. The biliary clearance of $\left[{ }^{14} \mathrm{C}\right]$ mannitol and $\left[{ }^{3} \mathrm{H}\right]$ sucrose was calculated as the product of bile flow and the bile-toplasma ratio (B/P) of radioactivity. Total bile acids in bile were estimated by the hydroxysteroid dehydrogenase procedure as previously described (17). Total bile acids in serum were quantitated with Enzabile (Seragen Diagnostics, Indianapolis, IN). Serum levels of glucose, total and conjugated bilirubin, alkaline phosphatase, alanine amino transferase, aspartate amino transferase, $\gamma-\mathrm{GT}$, total protein, albumin, globulins, and cholesterol; and serum and bile concentrations of sodium, potassium, chloride, and bicarbonate (measured as total $\mathrm{CO}_{2}$ ) were obtained by standard clinical chemistry methods with the SMAC (Technicon, Tarrytown, NY) and Monarch (Allied Instrumentation Laboratory, Lexington, MA) systems. Bile osmolality was measured by freezing point depression (Osmette, Precision Systems, Inc., Sudbury, MA). Cholesterol and phospholipid concentrations in bile were determined enzymatically, using commercial kits from Boehringer-Mannheim, Indianapolis, IN, and Wako Chemicals, Dallas, TX, respectively. Amylase activity in serum and bile was determined with the Phadebas amylase test (Pharmacia Fine Chemicals, Piscataway, NJ). Blood samples were collected for serum chemistry, erythrocyte and leukocyte counts, and for hematocrit determination. Hepatic $\mathrm{H}_{2} \mathrm{O}$ content was determined by the difference between wet and dried $\left(95^{\circ} \mathrm{C}\right)$ weights of liver specimens. Statistical differences were established by the paired and nonpaired Student's $t$ test.

\section{Results}

Serum chemistry and hematologic findings. The results are summarized in Table I. In BO rats, electrolyte serum concentrations were normal, but serum levels of cholesterol, bilirubin, phospholipid, and bile acids were all increased. Biochemical activities of alkaline phosphatase, alanine amino transferase, aspartate amino transferase, and $\gamma$-GT were also higher in the obstructed rats, whereas serum glucose and albumin levels were lower. Consistent with previous observations (18), mild anemia and leukocytosis were present in BO animals. The latter could be accounted for by an increase in neutrophyls and lymphocytes.

Liver histology and histochemistry. In the control shamoperated rat, hepatic morphology was normal. In all BO animals studied, DCH was the most striking structural abnormality. Portal inflammation and moderate peribiliary fibrosis were also observed. DCH was already seen $7 \mathrm{~d}$ after BO, but a more extensive proliferation of bile-ductlike cells was observed 12-16 d after obstruction was produced (Fig. 1). At this time, lobular architecture was preserved, yet at least six bile ductules/ducts were present per portal area, as opposed to one to two seen in the control liver. In BO animals, DCH was also demonstrated by histochemical staining of frozen liver sections for $\gamma$-GT. In control livers, $\gamma$-GT activity was confined to the biliary epithelial cells and only one to two positive bile ductules/ducts were observed per portal area (Fig. $2 A$ ). In obstructed livers, studied 12-16 d after induction of BO, histochemical expression of $\gamma$-GT was also confined to biliary structures within portal areas, but the number of bile-ductlike structures positive for the enzyme was much greater (Fig. $2 B$ ).

Biliary physiology. Because the histologic and histochemical results indicated that extensive DCH was present in rats
Table I. Serum Chemistry and Hematologic Data in Control Rats and in Rats with Biliary Obstruction

\begin{tabular}{llcc}
\hline & Unit & $\begin{array}{c}\text { Controls } \\
(n=5-10)\end{array}$ & $\begin{array}{l}\text { BO rats } \\
(n=6-9)\end{array}$ \\
\hline $\mathrm{Na}^{+}$ & $\mathrm{mEq} / \mathrm{liter}$ & $141.6 \pm 2.6$ & $142.3 \pm 1.5$ \\
$\mathrm{~K}^{+}$ & $\mathrm{mEq} / \mathrm{liter}$ & $4.7 \pm 0.7$ & $5.2 \pm 0.7$ \\
$\mathrm{Cl}^{-}$ & $\mathrm{mEq} / \mathrm{liter}$ & $101.4 \pm 2.3$ & $103.5 \pm 1.3$ \\
$\mathrm{HCO}_{3}^{-}$ & $\mathrm{mEq} / \mathrm{liter}$ & $27.5 \pm 4.6$ & $27.2 \pm 3.2$ \\
Glucose & $\mathrm{mg} / 100 \mathrm{ml}$ & $175.8 \pm 22.6$ & $120.9 \pm 14.5^{*}$ \\
Total cholesterol & $\mathrm{mg} / 100 \mathrm{ml}$ & $59.6 \pm 10.2$ & $84.9 \pm 12.8^{*}$ \\
Phospholipids & $\mathrm{mg} / 100 \mathrm{ml}$ & $119.4 \pm 21.3$ & $194.2 \pm 33.2^{*}$ \\
Bile acids & $\mu \mathrm{Eq} / \mathrm{liter}$ & $12.6 \pm 8.5$ & $253.2 \pm 98.1^{*}$ \\
Bilirubin (total) & $\mathrm{mg} / 100 \mathrm{ml}$ & $0.4 \pm 0.07$ & $7.2 \pm 1.3^{*}$ \\
Bilirubin (conjugated) & $\mathrm{mg} / 100 \mathrm{ml}$ & $0.1 \pm 0.05$ & $6.0 \pm 1.1^{*}$ \\
Total protein & $\mathrm{g} / 100 \mathrm{ml}$ & $5.5 \pm 0.4$ & $5.4 \pm 0.6$ \\
Globulins & $\mathrm{g} / 100 \mathrm{ml}$ & $2.2 \pm 0.3$ & $2.4 \pm 0.5$ \\
Albumin & $\mathrm{g} / 100 \mathrm{ml}$ & $3.3 \pm 0.2$ & $2.7 \pm 0.3^{*}$ \\
Alkaline phosphatase & $\mathrm{U} / \mathrm{liter}$ & $231.5 \pm 46.3$ & $627.8 \pm 76.4^{*}$ \\
Alanine amino & & & \\
$\quad$ transferase & $\mathrm{U} / \mathrm{liter}$ & $67.4 \pm 7.5$ & $275.6 \pm 39.6^{*}$ \\
Aspartate amino & & & \\
$\quad$ transferase & $\mathrm{U} / \mathrm{liter}$ & $119.6 \pm 26.4$ & $618.8 \pm 73.3^{*}$ \\
$\gamma$-GT & $\mathrm{U} / \mathrm{liter}$ & $1.8 \pm 0.8$ & $20.9 \pm 8.2^{*}$ \\
Erythrocytes & $10^{6} / \mu \mathrm{l}$ & $6.8 \pm 0.7$ & $5.9 \pm 0.6$ \\
Leukocytes & $10^{3} / \mu \mathrm{l}$ & $5.1 \pm 0.8$ & $23.8 \pm 11.2^{*}$ \\
Hematocrit & $\%$ & $42.4 \pm 2.3$ & $35.9 \pm 2.9^{*}$ \\
& & & \\
\hline & & & \\
\hline
\end{tabular}

Analyses were performed $14 \mathrm{~d}$ after induction of BO or 12-14 d after rats were sham-operated (controls). ${ }^{*} P<0.05-0.001$ when compared with the control value.

obstructed for 12-16 d without major alterations in parenchymal architecture, the biliary physiology studies were all carried out $14 \mathrm{~d}$ after induction of $\mathrm{BO}$. A representative experiment is shown in Fig. 3, and all the results are summarized in Table II and Fig. 4. The major findings can be outlined as follows.

(a) Steady-state bile flow, achieved within 30-50 min from the release of the obstruction in experimental rats and within 20-40 min from cannulation of the common bile duct in physiologic animals (Fig. 3), was much higher in BO rats than in controls. The increase in spontaneous bile flow in the obstructed rats was associated with an increased biliary clearance of $\left[{ }^{14} \mathrm{C}\right]$ mannitol, although solute $\mathrm{B} / \mathrm{P}$ was lower in $\mathrm{BO}$ rats. Conversely, biliary entry of $\left[{ }^{3} \mathrm{H}\right]$ sucrose was much higher in $\mathrm{BO}$ rats, and solute biliary clearance was $\sim 15$ times greater in obstructed rats than in controls. Under steady-state conditions, the excretion rate of cholesterol, phospholipid, and bile acids were the same in controls and $\mathrm{BO}$ rats. Mean bicarbonate concentration in bile was also the same in the two groups of animals, but bicarbonate concentrations in $\mathrm{BO}$ rats varied significantly from animal to animal (13-29 $\mathrm{mEq} / \mathrm{liter})$. Interestingly, bicarbonate biliary concentrations in BO rats were significantly higher $(P<0.05$ by the paired $t$ test $)$ immediately after biliary obstruction was released $(25-39 \mathrm{mEq} / \mathrm{liter})$ than when steady-state secretory conditions were reached.

(b) Taurocholate ( $5 \mu \mathrm{mol} / \mathrm{min}$ per $\mathrm{kg}$ ) produced essentially the same effects in controls and BO rats. Bile flow, $\left[{ }^{14} \mathrm{C}\right] \mathrm{mannitol}$ biliary clearance, and biliary excretions of bile acids, phospholipid, and cholesterol all increased by the same 


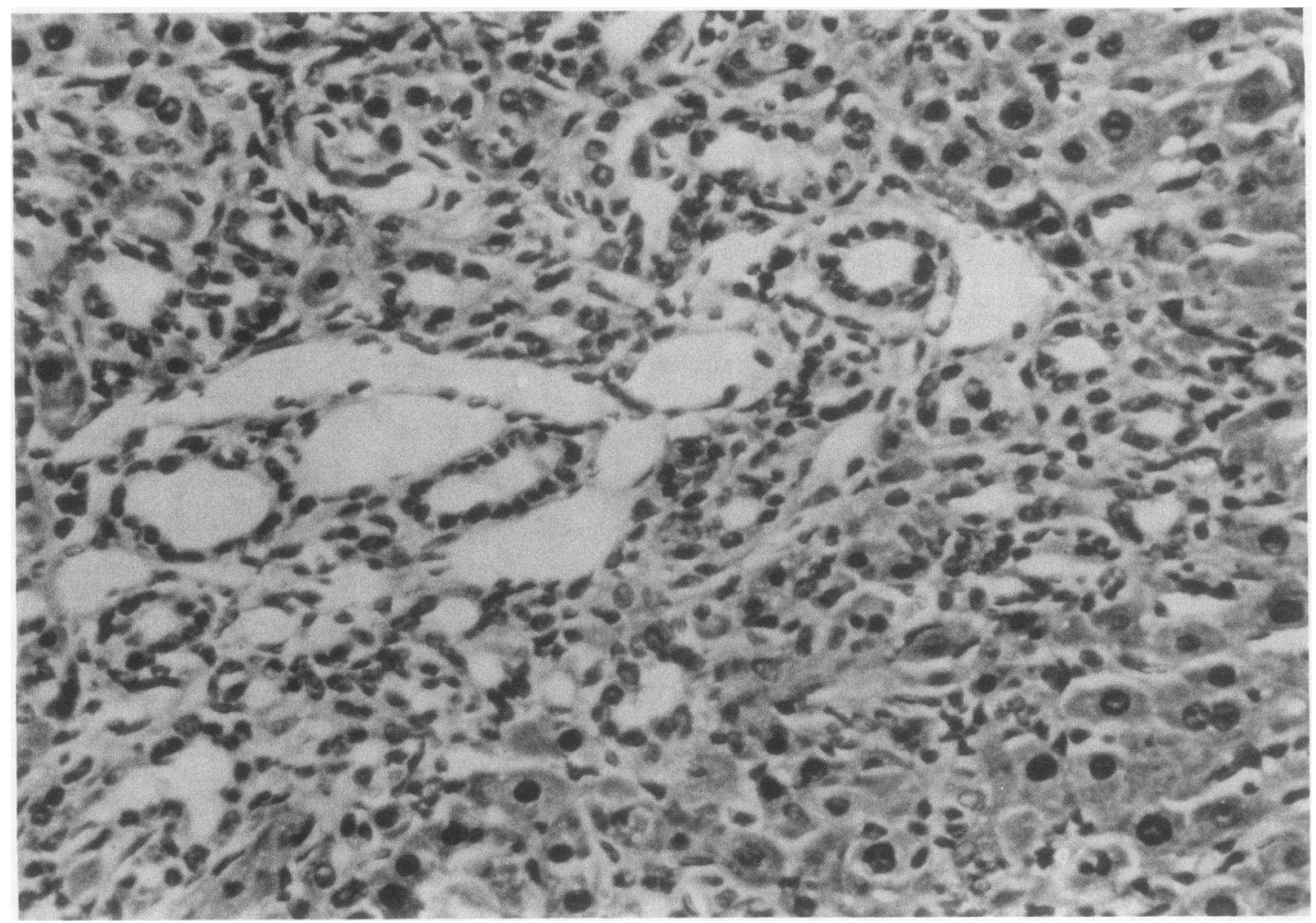

Figure 1. Portal area of a liver from a rat obstructed for $14 \mathrm{~d}$. Note extensive proliferation of bile-ductlike structures, slight infiltration with inflammatory cells, and mild peribiliary fibrosis. No significant hepatocellular necrosis is observed (H \& $E, \times 64)$.

magnitude in both groups of animals, whereas bicarbonate biliary concentrations slightly and similarly decreased. The only difference was the effect of taurocholate on $\left[{ }^{3} \mathrm{H}\right]$ sucrose biliary clearance, which was much greater in $\mathrm{BO}$ rats than in controls.

(c) Unlike taurocholate, secretin $(10 \mathrm{CU} / \mathrm{kg}$ per h) produced quite different effects when infused for 30-40 min into controls or BO rats. In controls, the hormone induced a minimal choleresis with no measurable change in bile composition. In obstructed rats, secretin produced a massive increase in bile flow and bicarbonate concentrations in bile. During secretin choleresis, $\left[{ }^{14} \mathrm{C}\right]$ mannitol B/P declined but solute biliary clearance partially and significantly increased. On the other hand, $\left[{ }^{3} \mathrm{H}\right]$ sucrose biliary clearance was not affected by the choleretic effect of the hormone. As expected, the increase in bile flow produced by secretin in BO rats was associated with no measurable change in the biliary excretion of bile acids, cholesterol, and phospholipid.

Biliary amylase activity. To ascertain that in BO animals bile was not contaminated with pancreatic juice, which could account for the apparent biliary effects of secretin, $\alpha$-amylase activity in serum and bile was determined in three controls and three BO rats (obstructed for $14 \mathrm{~d}$ ). Under spontaneous bile secretion, serum amylase activity averaged $2,475 \mathrm{U} /$ liter in controls and 1,253 U/liter in BO animals, and biliary amylase output averaged 0.72 and $0.25 \mu \mathrm{U} / \mathrm{min}$ per $\mathrm{g}$ liver in the two groups, respectively. During secretin administration in BO rats, enzyme plasma levels remained virtually unchanged $(1,308 \mathrm{U} /$ liter) but biliary amylase activity declined from the average basal value of $65 \mathrm{U} /$ liter to $53 \mathrm{U} /$ /iter, so that steady- state biliary amylase output $(0.28 \mu \mathrm{U} / \mathrm{min}$ per $\mathrm{kg})$ was essentially the same as that under unstimulated conditions. These results are consistent with those previously reported $(19,20)$ and indicate that, both in controls and BO rats, bile was not contaminated with pancreatic juice.

Biliary tree volume determination. The results from these experiments are reported in Fig. 5 and Table III. In control rats, BTV measured during taurocholate choleresis averaged $2.93 \mu \mathrm{l} / \mathrm{g}$ liver or $32.8 \mu \mathrm{l} /$ total liver. This value is similar to that obtained previously in the rat using a somewhat different technique (21). Secretin produced only a minimal increase in bile flow in control rats so that BTV could not be measured during administration of the hormone. In BO rats, BTV determined during taurocholate choleresis $(67.4 \mu \mathrm{l} / \mathrm{g}$ liver or $1071.9 \mu \mathrm{l} /$ total liver), was much greater than that obtained in controls, presumably due to the dilated biliary passages $(22,23)$ and increased number and/or length of bile ductules/ducts. During secretin choleresis, BTV was invariably lower than that measured during the increase in flow produced by taurocholate, regardless of whether it was expressed per unit of liver weight or per total liver mass.

Cytochemistry and immunocytochemistry of isolated hepatocytes and nonparenchymal liver cells. The results are shown in Tables IV and V. In controls, the number and average size of isolated hepatocytes and nonparenchymal liver cells were within the expected range $(24,25)$. In $B O$ rats, the number of isolated hepatocytes was $85 \%$ of that recovered in controls when expressed per unit of liver weight, and $62 \%$ when expressed per total liver mass. The average size of parenchymal liver cells isolated from BO rats was slightly yet significantly 

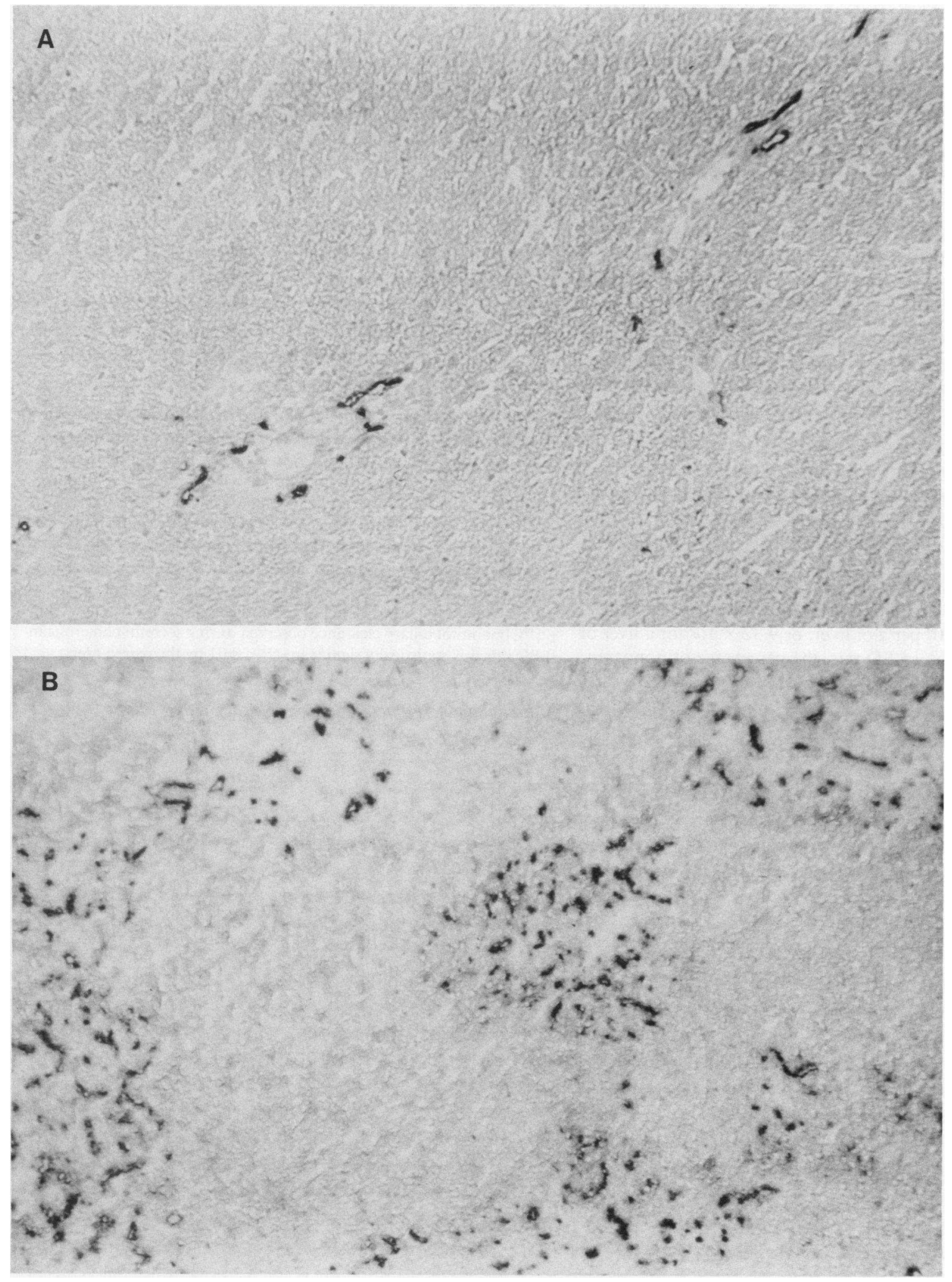

Figure 2. Histochemical expression of $\gamma$-glutamyl transpeptidase in the livers of a normal rat $(a)$ and of a rat obstructed for $14 \mathrm{~d}(b)$. Note that while the enzyme activity is confined to portal areas in both livers, the number of bile-ductlike structures positive for the enzyme is much greater in the obstructed liver (frozen sections counterstained with hematoxylin, $\times 64$ ).

smaller than that of hepatocytes isolated from controls. On the other hand, the yield of nonparenchymal liver cells was significantly greater in BO rats than in controls, regardless of whether cell number was expressed per gram of liver or per total liver mass. The average diameter of nonparenchymal liver cells isolated from $\mathrm{BO}$ animals was also greater, presumably reflecting 


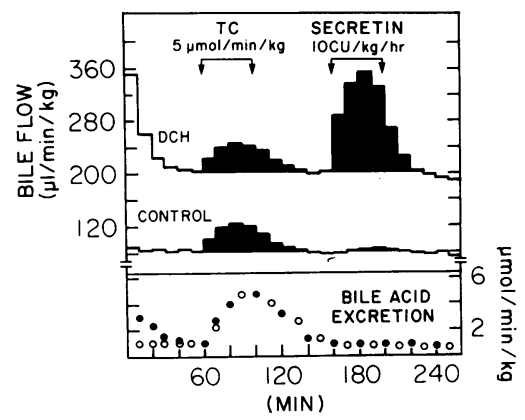

Figure 3. Bile flow and bile acid excretion rates in a control rat and in a rat obstructed for $14 \mathrm{~d}$ (DCH rat). Four points of the results need emphasis: (a) steady-state spontaneous bile flow was much higher in the obstructed animal; $(b)$ taurocholate $(T C)$ produced the same choleretic effects in both animals; $(c)$ secretin increased minimally bile flow in the control rat, but produced a massive choleresis in the BO animal; and $(d)$ the excretion rate of 3-hydroxy bile acids was the same in the two animals ( $\bullet$, BO rat; $\bigcirc$, control rat) both under spontaneous secretory conditions (when steady-state was achieved) and during taurocholate choleresis ( $>90 \%$ of the infused taurocholate was recovered in bile).

the higher percentage of biliary epithelial cells (which are on the average larger than endothelial cells) present in BO livers. Cytochemical staining of nonparenchymal liver cell smears for $\gamma$-GT revealed that, in control rats, only $3.6-4.8 \%$ of cells were positive for the enzyme. Thus, the average number of biliary epithelial cells isolated and recovered with the present procedure was $0.78 \times 10^{6}$ per $\mathrm{g}$ of liver, or $9.32 \times 10^{6}$ for a liver of approximately $12 \mathrm{~g}$. In BO rats, the percentage of nonparen-

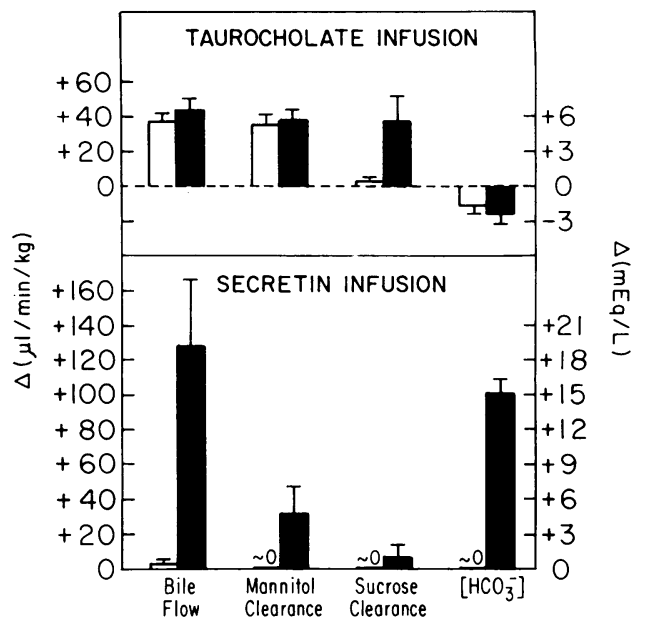

Figure 4. Net changes $(\Delta)$ in bile flow and mannitol and sucrose biliary clearances (all expressed in $\mu \mathrm{l} / \mathrm{min}$ per $\mathrm{kg}$ ), and in bicarbonate biliary concentrations $(\mathrm{mEq} / \mathrm{liter})$ in control rats $(n=8-11$, open bars) and in rats obstructed for $14 \mathrm{~d}(n=7-10$, solid bars) produced by taurocholate $(5 \mu \mathrm{mol} / \mathrm{min}$ per $\mathrm{kg})$ and secretin $(10 \mathrm{CU} / \mathrm{kg}$ per h) infusion. Taurocholate produced the same effects in both groups of rats, except for the effect on $\left[{ }^{3} \mathrm{H}\right]$ sucrose biliary clearance which was significantly $(P<0.05)$ greater in $\mathrm{BO}$ rats. In control rats, secretin minimally increased bile flow and did not increase biliary clearances of $\left[{ }^{14} \mathrm{C}\right]$ mannitol and $\left[{ }^{3} \mathrm{H}\right]$ sucrose. On the other hand, the increase in $\left[{ }^{14} \mathrm{C}\right]$ mannitol biliary clearance observed during secretin choleresis in BO rats was statistically significant $(P<0.01$ by the paired $t$ test $)$.

Table II. Bile Flow and Composition and Biliary Clearance of $\left[{ }^{14} \mathrm{C}\right]$ Mannitol and $\left[{ }^{3} \mathrm{H}\right]$ Sucrose in Control Rats and in Rats with Biliary Obstruction

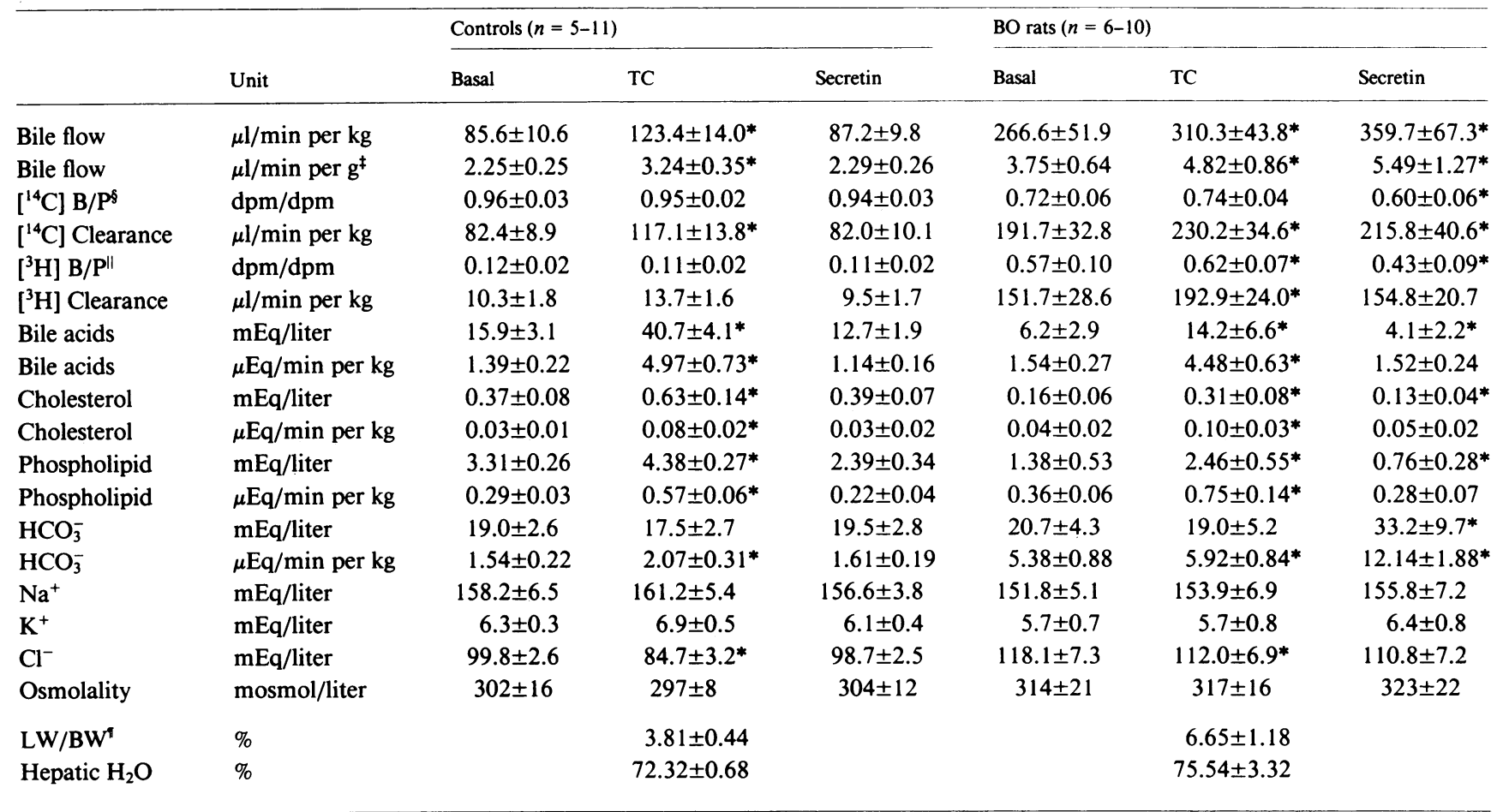

Data are means $\pm \operatorname{SD}(n=$ no. of animals) and were obtained at steady-state conditions. Rats were studied $14 \mathrm{~d}$ after induction of BO or $12-14$ $\mathrm{d}$ after being sham-operated (controls). Note that basal values shown here are those obtained during the initial period in which bile collection was initiated ( $0-70 \mathrm{~min})$ and are not necessarily the same as those observed before secretin infusion. Thus, for net changes produced by the hormone, see Fig. 4. Taurocholate (TC) was infused at $5 \mu \mathrm{mol} / \mathrm{min}$ per $\mathrm{kg}$, while secretin at $10 \mathrm{CU} / \mathrm{kg}$ per h. ${ }^{*}$ Significantly different $(P<0.05-0.001$ by paired $t$ test $)$ when compared with respective basal value. ${ }^{\ddagger} \mu \mathrm{l} / \mathrm{min}$ per $\mathrm{g}$ liver. ${ }^{8}\left[{ }^{14} \mathrm{C}\right]$ stands for $\left[{ }^{14} \mathrm{C}\right] \mathrm{mannitol}$. $\left.\quad{ }^{\|[} \mathrm{H}\right]$ stands for $\left[{ }^{3} \mathrm{H}\right]$ sucrose. " Liver weight/body weight. 


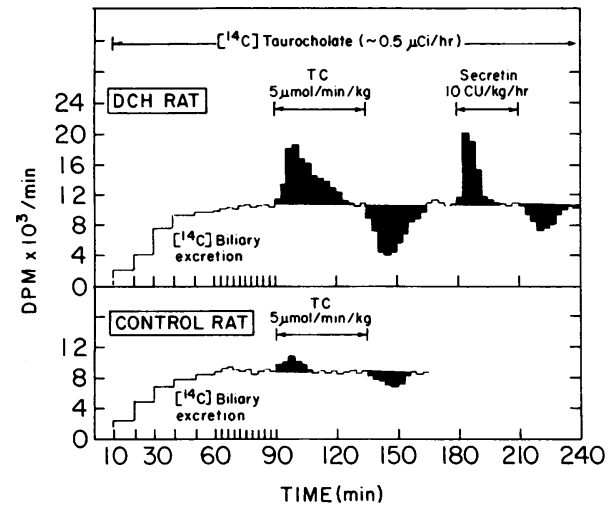

Figure 5. Biliary tree volume determination in a control rat and in a rat obstructed for $14 \mathrm{~d}(\mathrm{DCH}$ rat). Animals received a constant infusion of trace amounts of $\left[{ }^{14} \mathrm{C}\right]$ taurocholate $(\sim 10 \mathrm{nmol} / \mathrm{h})$ as a marker of biliary transit time. When steady-state biliary excretion of radioactivity was observed, $5 \mu \mathrm{mol} / \mathrm{min}$ per $\mathrm{kg}$ taurocholate (TC) were infused for $45 \mathrm{~min}$ followed by (a) a 60 -min equilibrium period; (b) a constant infusion of secretin at $10 \mathrm{CU} / \mathrm{kg}$ per $\mathrm{h}$ for 30 $\mathrm{min}$; and $(c)$ a final 30-min equilibration period. The biliary tree volume was calculated (see Methods) by measuring the biliary washouts (solid areas) of $\left[{ }^{14} \mathrm{C}\right]$ radioactivity during choleresis produced by the bile acid and the hormone. (In the control rat only taurocholate was infused because secretin did not produce a sufficient increase in bile flow to allow measurement of biliary washout of $\left[{ }^{14} \mathrm{C}\right]$ radioactivity.) Note that in the DCH rat, the biliary washout of $\left[{ }^{14} \mathrm{C}\right]$ radioactivity was much greater during taurocholate than secretin choleresis. Also note that the biliary washout of radioactivity associated with taurocholate choleresis was greater in the obstructed animal than in the control.

chymal liver cells expressing $\gamma$-GT activity ranged from 25 to 31 so that the number of $\gamma$-GT positive cells was $10-15$ times greater than that recovered in controls. Immunoperoxidase staining for cytokeratin, which is also a marker of epithelial cells (26), yielded roughly the same percentage of positive nonparenchymal cells as that obtained with $\gamma$-GT. Hepatocytes, isolated from either control or BO rats, were negative for $\gamma$-GT, cytokeratin, and $\alpha$-fetoprotein, and positive for G-6-P and albumin. Nonparenchymal liver cells were always negative for G-6-P, albumin, and $\alpha$-fetoprotein, regardless of whether they were isolated from controls or $\mathrm{BO}$ rats.

\section{Discussion}

Several observations suggest that the biliary ductules/ducts are involved in bile formation. At least in the rat, however, little is known about the reabsorptive and secretory activities of biliary epithelial cells. In the present studies, we have examined several aspects of biliary physiology in rats with DCH in the attempt to obtain more direct evidence for a role of biliary epithelium in bile formation. Our line of reasoning was that if the bile ductules/ducts were involved in secretion or reabsorption of bile, then conditions associated with an increased number of biliary epithelial cells, as in prolonged BO, should result in an amplified secretory or reabsorptive activity. The present results have indeed demonstrated that induction of DCH is associated with a massive increase in spontaneous bile flow and responsiveness to secretin choleresis. Our findings are consistent with previous reports which have shown that bile duct obstruction $(10,11)$ and $\alpha$-naphthylisothiocyanate feeding (9), which also induces DCH, are associated with an increased spontaneous bile secretion (9-11) and/or responsiveness to secretin choleresis (10). Unlike these previous studies, however, the present experiments provide compelling evidence that the proliferated bile ductules/ducts are the structures responsible for the increased secretory activity, both under spontaneous conditions and during secretin administration.

The conclusion that the proliferated biliary epithelial cells secrete water and electrolytes and are the site of secretin choleresis is based on the following observations. First, induction of BO led to an unambiguous increase in the number and/or length of bile ductules/ducts, and to a moderate but significant decrease in both the size and number of parenchymal cells, making it unrealistic to implicate the latter as the structures responsible for the increased secretory activity. Second, the composition of bile in $\mathrm{BO}$ rats both under unstimulated conditions and during secretin choleresis resembled that of a fluid secreted primarily at the distal, rather than canalicular, region of the biliary tree. Bicarbonate concentrations in spontaneously secreted bile were in fact, the same as, or higher (immediately after the obstruction was released) than in controls and, as observed in other species $(4,27)$, significantly increased during secretin choleresis. Although bicarbonate transport may be involved in hepatocytic bile formation $(28,29)$, available evidence favors a ductular/ductal localization of such a process, at least of the one responsive to secretin stimulation $(4,27)$. Third, $\left[{ }^{14} \mathrm{C}\right]$ mannitol $\mathrm{B} / \mathrm{P}$ under spontaneous secretory conditions was much lower in $\mathrm{BO}$ animals, even though solute biliary clearance was significantly higher. We now know that this, as well as other inert carbohydrates can cross the distal epithelial structures $(30,31)$ so that firm conclusions about the site at which bile is secreted or reabsorbed cannot be made on

Table III. Biliary Tree Volumes in Control Rats and in Rats with Biliary Obstruction Measured during Secretin and/or Taurocholate Cholereses

\begin{tabular}{lllll}
\hline & \multicolumn{2}{l}{ Taurocholate choleresis } & & \multicolumn{2}{l}{ Secretin choleresis } \\
\cline { 2 - 3 } & $\mu 1 / \mathrm{g}$ liver & $\mu \mathrm{l} /$ total liver & & $\mu \mathrm{l} / \mathrm{g}$ liver \\
\hline Controls $(n=4)$ & $2.93 \pm 0.56$ & $32.8 \pm 5.1$ & - & - \\
BO rats $(n=6)$ & $67.4 \pm 15.8^{*}$ & $1071.9 \pm 162.6^{*}$ & $39.5 \pm 10.4^{\ddagger}$ & $628.4 \pm 74.8^{\ddagger}$ \\
BO/control & 23.0 & 32.7 & - & -
\end{tabular}

Values are means $\pm \mathrm{SD}$ ( $n=$ No. of experiments). Experiments were carried out $14 \mathrm{~d}$ after induction of BO or $14 \mathrm{~d}$ after rats were sham-operated (controls). * Significantly different $(P<0.001)$ when compared with the respective values obtained in controls. ${ }^{\ddagger}$ Significantly different $(P<0.01$ by the paired $t$ test) when compared with the respective values obtained during taurocholate choleresis. 
Table IV. Average Size and Number of Hepatocytes and Nonparenchymal Liver Cells, and Number of Nonparenchymal Cells Positive for $\gamma-G T$, Isolated from Control Rats and from Rats with Biliary Obstruction

\begin{tabular}{|c|c|c|c|}
\hline & Controls $(n=6)$ & BO rats $(n=8)$ & $\mathrm{BO} /$ control \\
\hline \multicolumn{4}{|l|}{ Hepatocytes } \\
\hline Diameter $(\mu m)$ & $22.53 \pm 0.51$ & $19.16 \pm 0.82^{*}$ & 0.85 \\
\hline No./total liver & $5.61 \pm 0.23 \times 10^{8}$ & $4.78 \pm 0.43 \times 10^{8 *}$ & 0.85 \\
\hline \multicolumn{4}{|c|}{ Nonparenchymal liver cells } \\
\hline No./total liver & $2.23 \pm 0.45 \times 10^{8}$ & $4.82 \pm 0.58 \times 10^{8 *}$ & 2.16 \\
\hline \multicolumn{4}{|c|}{$\begin{array}{l}\text { Nonparenchymal liver cells positive } \\
\text { for } \gamma-G^{\ddagger}\end{array}$} \\
\hline$\%$ & $4.18 \pm 0.22$ & $28.65 \pm 2.53^{*}$ & 6.85 \\
\hline No./g liver & $0.78 \pm 0.12 \times 10^{6}$ & $8.38 \pm 1.08 \times 10^{6 *}$ & 10.74 \\
\hline
\end{tabular}

Values are means $\pm \mathrm{SD}(n=$ no. of experiments). Cells were isolated 13-14 d after induction of BO or 12-14 d after rats were sham-operated (controls). * Significantly different $(P<0.05-0.001)$ when compared with the respective control value. ${ }^{\ddagger}$ The number of cells (biliary epithelial) positive for $\gamma$-GT was roughly the same as that estimated by cytokeratin immunohistochemistry (see Table V).

the basis of these clearance measurements. However, it is reasonable to assume that the collecting bile ductules/ducts are less permeable to $\left[{ }^{14} \mathrm{C}\right]$ mannitol than the bile canaliculi so that the lower solute $\mathbf{B} / \mathbf{P}$ observed in the obstructed rats can best be explained by postulating that the additional fluid secreted in BO animals originated at the distal epithelial structures. The finding that during secretin choleresis, biliary entry of $\left[{ }^{14} \mathrm{C}\right]$ mannitol increased only partially, as observed in other species $(32,33)$, and that of the larger solute $\left[{ }^{3} \mathrm{H}\right]$ sucrose was virtually unaffected is in accord with this interpretation. Fourth, BTV in BO rats measured during secretin choleresis was significantly smaller than that determined during choleresis produced by the canalicular stimulant taurocholate, a finding similar to that obtained previously in the $\operatorname{dog}(4)$ and construed to support a ductular/ductal origin of secretin choleresis. Finally, secretin induced a minimal choleresis in physiologic rats but a massive increase in bile flow in BO animals in which extensive DCH was present, whereas the canalicular stimulant taurocholate produced the same biliary effects in both groups of animals. If not for the increased number of biliary epithelial cells, why would other factors, such as the hematologic abnormalities and/or the biochemical, regenerative $(34,35)$, structural $(22,23,36)$, and permeability (increased $\left[{ }^{3} \mathrm{H}\right]$ sucrose biliary entry) changes, which also occur in $\mathrm{BO}$, lead to an increased spontaneous secretory activity and responsiveness to secretin choleresis, and not modify the biliary effects of taurocholate? Taken together, therefore, the present results provide compelling evidence that, in BO rats, the proliferated bile ductules/ducts spontaneously secrete water and electrolytes and are the site of secretin choleresis.

Because DCH is a toxic hepatic reaction seen in obstruction $(34,37)$ and in a variety of hepatobiliary diseases $(38-40)$, we judged it of importance to establish the origin of the proliferated cells in our BO rats. In fact, if the secretory activity of the proliferated structures represented an acquired property of the newly formed cells, then the physiologic relevance of our findings would be uncertain. At present, the significance of $\mathrm{DCH}$, including the origin and fate of the proliferating cells, is

Table V. Phenotypic Characteristics of Hepatocytes and Nonparenchymal Liver Cells Isolated from Control Rats and from Rats with Biliary Obstruction

\begin{tabular}{|c|c|c|c|c|}
\hline & \multicolumn{2}{|c|}{ Controls $(n=8-18)$} & \multicolumn{2}{|c|}{ BO rats $(n=15-26)$} \\
\hline & Hepatocytes & $\begin{array}{l}\text { Nonparenchymal } \\
\text { cells }\end{array}$ & Hepatocytes & $\begin{array}{l}\text { Nonparenchymal } \\
\text { cells }\end{array}$ \\
\hline Glucose-6-phosphatase & + & - & + & - \\
\hline$\gamma$-Glutamyl transpeptidase & - & $+^{*}$ & - & $+^{*}$ \\
\hline Cytokeratin & $-\neq$ & $t^{8}$ & $-\neq$ & +8 \\
\hline Albumin & + & - & + & - \\
\hline$\alpha$-Fetoprotein & +11 & - & - & - \\
\hline
\end{tabular}

Cells were isolated 13-14 d after induction of BO or 12-14 d after rats were sham-operated (controls). (+) Activity. ( - ) No activity. * $4.18 \%$ and $28.65 \%$ of cells were positive for $\gamma$-GT in controls and DCH rats, respectively (see Table IV). ${ }^{\ddagger}$ Hepatocytes from control and BO rats were negative, although some pale staining was at times observed in a few cells. $\$ 4-5 \%$ and $25-30 \%$ of cells were strongly positive in controls and BO rats, respectively (as for $\gamma$-GT). "Isolated from fetal rat livers (hepatocytes isolated from normal adult rats were negative). 
not fully understood. Some reports have suggested that metaplasia of hepatocytes may in part account for the proliferated bile-ductlike structures seen in various forms of chronic liver disease associated with cholestasis (41-43). In these and other studies $(44,45)$, however, the hyperplastic, nonparenchymal cell population associated with biliary obstruction was invariably negative for G-6-P, albumin, and/or $\alpha$-fetoprotein, whereas $\gamma$-GT activity and cytokeratin expression were consistently detected. Clearly, this does not prove that the proliferated bile ductules/ducts were derived solely from the existing biliary epithelial structures, nor that they retained fully the physiologic properties of bile ductular epithelial cells. In fact, it is possible that secretion of water and electrolytes is an acquired property of the proliferated cells secondary to the nonphysiologic conditions (e.g., stagnant bile acids and/or other bile constituents in the biliary ductules/ducts) associated with obstruction. However, in addition to the phenotypic data which do support a biliary epithelial origin of the proliferated cells, the augmented responsiveness to secretin choleresis was roughly proportional to the increase in BTV and the number of $\gamma$-GT positive cells. This suggests that the secretory activity of the proliferated biliary structures represents a quantitative, rather than a qualitative change associated with $\mathrm{DCH}$. Hence, although under normal conditions the biliary ductules/ducts in the rat seem to contribute little to bile secretion, they do appear to have the property of secreting a bicarbonate-rich fluid both spontaneously and under the stimulating effect of the hormone secretin.

As to the mechanism by which the proliferated biliary epithelial cells secrete fluid, the finding that the stagnant bile collected immediately after the obstruction was released and during secretin choleresis contained high bicarbonate concentrations supports the existing hypothesis that bicarbonate transport is somehow involved in the vectorial transport of water across the biliary ductules/ducts. At this time, however, this is only conjectural and further studies are needed to elucidate the precise mechanism by which the biliary epithelial cells secrete water and electrolytes.

\section{Acknowledgments}

We wish to thank Drs. P. D. Berk, H. Popper, and F. Schaffner for fruitful discussions related to this work. We would also like to express our gratitude to Ms. Mary Barrett for her assistance in editing this manuscript.

This work was supported by grant HD 17556 from the National Institute of Child Health and Human Development.

\section{References}

1. Blitzer, B. L., and J. L. Boyer. 1982. Cellular mechanisms of bile formation. Gastroenterology. 82:346-357.

2. Erlinger, S. 1981. Hepatocyte bile secretion: current views and controversies. Hepatology (Baltimore). 1:352-359.

3. Wheeler, H. O., O. L. Ramos, and R. T. Whitlock. 1960. Electrolyte excretion in bile. Circulation. 21:988-996.

4. Wheeler, H. O., and P. L. Mancusi-Ungaro. 1966. Role of bile ducts during secretin choleresis in dogs. Am. J. Physiol. 210:11531159.

5. Wheeler, H. O., E. D. Ross, and S. E. Bradley. 1968. Canalicular bile production in dogs. Am. J. Physiol. 214:866-874.

6. Tavoloni, N. 1985. Role of ductular bile water reabsorption in canine bile secretion. J. Lab. Clin. Med. 106:154-161.
7. Hashmonai, M., I. Kam, and A. Schramek. 1984. The etiology of "white bile" in the biliary tree. J. Surg. Res. 37:479-486.

8. Nahrwold, D. L. 1971. Secretion by the common duct in response to secretin. Surg. Forum. 22:386-387.

9. Goldfarb, S., E. J. Singer, and H. Popper. 1963. Biliary ductules and bile secretion. J. Lab. Clin. Med. 62:608-615.

10. Kountouras, J., S. McKavanagh, M. Burmicky, and B. H. Billing. 1986. The effect of secretin on bile flow and bile acid and bilirubin excretion following relief of prolonged bile duct obstruction in the rat. J. Hepatol. 4:198-205.

11. Accatino, L., A. Contreras, S. Fernandez, and C. Quintana. 1979. The effect of complete biliary obstruction on bile flow and bile acid excretion: postcholestatic choleresis in the rat. J. Lab. Clin. Med. 93:706-717.

12. Tavoloni, N. 1984. Permeation patterns of polar nonelectrolytes across the guinea pig biliary tree. Am. J. Physiol. 247:G527G536.

13. Ronchi, G., and V. J. Desmet. 1973. Histochemical study of gammaglutamyl transpeptidase in experimental intrahepatic and extrahepatic cholestasis. Beitr. Pathol. 150:316-321.

14. Rutenberg, A. M., H. Kim, J. W. Fishbein, J. S. Hanker, H. L. Wasserkrug, and A. M. Seligman. 1969. Histochemical and ultrastructural demonstration of $\gamma$-glutamyl transpeptidase activity. J. Histochem. Cytochem. 17:517-526.

15. Yaswen, P., N. T. Hayner, and N. Fausto. 1984. Isolation of oval cells by centrifugal elutriation and comparison with other cell types purified from normal and preneoplastic livers. Cancer Res. 44:324-331.

16. Wachstein, M., and E. Meisel. 1956. On the histochemical demonstration of glucose-6-phosphatase. J. Histochem. Cytochem. 4:592-597.

17. Tavoloni, N., and L. Angelucci. 1975. Polypeptide stimulation of choleresis in the dog. Rend. Gastroenterol. 7:165-172.

18. Center, S. A., B. H. Baldwin, J. M. King, and B. C. Tennant. 1983. Hematologic and biochemical abnormalities associated with induced extrahepatic bile duct obstruction in the cat. Am. J. Vet. Res. 44:1822-1829.

19. Ogawa, S. 1974. Biliary amylase excretion in rats especially in relation with the plasma level of the enzyme. Jpn. J. Gastroenterol. 71:316-326.

20. Grendell, J. H., and S. S. Rothman. 1982. Effect of changes in circulating amylase levels on amylase output in bile. Am. J. Physiol. 243:G54-G59.

21. Hacki, W., and G. Paumgartner. 1973. Determination of the biliary dead space using $\left[{ }^{14} \mathrm{C}\right]$ taurocholate as a marker. Experientia (Basel). 29:1091-1093.

22. Metz, J., A. Aoki, M. Merlo, and W. G. Forssmann. 1977. Morphological alterations and functional changes of interhepatocellular junctions induced by bile duct ligation. Cell Tissue Res. 182:299310.

23. Vital, A., P. Bioulac-Sage, A. Iron, and C. Balabaud. 1982. Morphologic structure of bile canaliculi after bile duct ligation in the rat. Arch. Pathol. Lab. Med. 106:464-467.

24. Berg, T., and D. Boman. 1973. Distribution of lysosomal enzymes between parenchymal and Kupffer cells of rat liver. Biochim. Biophys. Acta. 321:585-596.

25. Zahlten, R. N., H. K. Hagler, M. E. Nejtek, and C. J. Day. 1978. Morphological characterization of Kupffer and endothelial cells of rat liver isolated by counterflow elutriation. Gastroenterology. 75:80-87.

26. Franke, W. W., B. Appelhans, E. Schmid, C. Freudestein, M. Osborn, and K. Weber. 1979. Identification and characterization of epithelial cells in mammalian tissues by immunofluorescence microscopy using antibodies to prekeratin. Differentiation. 15:7-25.

27. Waitman, A. M., W. P. Dyck, and H. D. Janowitz. 1969. Effect of secretin and acetazolamide on the volume and electrolyte composition of hepatic bile in man. Gastroenterology. 56:286-294.

28. Hardison, W. G. M., and C. A. Wood. 1978. Importance of 
bicarbonate in bile salt independent fraction of bile flow. Am. J. Physiol. 235:E158-E164.

29. Garcia-Marin, J. J., M. Corbic, M. Dumont, G. DeCouet, and S. Erlinger. 1985. Role of $\mathrm{H}^{+}$transport in ursodeoxycholate-induced biliary $\mathrm{HCO}_{3}^{-}$secretion in the rat. Am. J. Physiol. 249:G335-G341.

30. Smith, N., and J. L. Boyer. 1982. Permeability characteristics of bile duct in the rat. Am. J. Physiol. 242:G52-G57.

31. Tavoloni, N., H. R. Wyssbrod, and M. J. T. Jones. 1986. Permeability characteristics of the guinea pig biliary apparatus. Hepatology (Baltimore). 6:1369-1381.

32. Barnhart, J. L., and B. Combes. 1978. Erythritol and mannitol clearances with taurocholate and secretin-induced cholereses. Am. J. Physiol. 234:E146-E156.

33. Larsen, J. A., and N. Krarup. 1978. The effect of secretin on bile production, splanchnohepatic hemodynamics and liver function in cats. Acta Physiol. Scand. 102:420-424.

34. MacDonald, R. A., and G. Pechet. 1961. Liver cell regeneration due to biliary obstruction. Arch. Pathol. 72:133-141.

35. Wu, P. C., M. A. Lily, J. B. Gibson, H. Hirai, and Y. Tsukada. 1981. Serum alpha-fetoprotein in rats after ligation of the common bile duct: relation to ductular cell (oval cell) proliferation. J. Pathol. 133:61-74.

36. Vial, J. D., F. R. Simon, and A. M. Mackinnon. 1976. Effect of bile duct ligation on the ultrastructural morphology of hepatocytes. Gastroenterology. 70:85-92.

37. Cameron, G., and C. Oakley. 1932. Ligation of the common bile duct. J. Pathol. Bacteriol. 35:769-798.
38. Uchida, T., and R. L. Peters. 1983. The nature and origin of proliferated bile ductules in alcoholic liver disease. Am. J. Clin. Pathol. 79:326-333.

39. Rubin, E., F. Schaffner, and H. Popper. 1965. Primary biliary cirrhosis. Am. J. Pathol. 46:387-407.

40. Goldfarb, S., E. J. Singer, and H. Popper. 1962. Experimental cholangitis due to alpha-naphthyl-isothiocyanate. Am. J. Pathol. 40:685-698.

41. Butron Vila, M. M., J. Haot, and V. J. Desmet. 1984. Cholestatic features in focal nodular hyperplasia of the liver. Liver. 4:387395.

42. Vanstapel, M. J., M. Butron, and V. J. Desmet. 1984. Keratin immunohistochemistry in normal and pathological human liver. Hepatology (Baltimore). 4:1037. (Abstr.)

43. Schulz, R., D. Schuppan, E. O. Riecken, and E. G. Hahn. 1986. The ductular metaplasia of hepatocytes: characterization of the pericellular matrix. Hepatology (Baltimore). 6:1149. (Abstr.)

44. Sirica, A. E., and H. P. Cihla. 1984. Isolation and partial characterizations of oval and hyperplastic bile ductular cell-enriched populations from the livers of carcinogen and non-carcinogen-treated rats. Cancer Res. 44:3454-3466.

45. Yokoyama, S., M. Satoh, and B. Lombardi. 1986. Bile ductular cells and phenotypic heterogeneity of the population of hepatic nonparenchymal epithelial cells induced in rats by chemical carcinogens. Carcinogenesis (Lond.). 7:1215-1219. 